\title{
O ensino do jazz: uma reflexão em torno de alguns dos seus contributos
}

\author{
Ricardo Pinheiro \\ Escola Superior de Música de Lisboa, \\ Instituto Politécnico de Lisboa, Portugal \\ Feodor Bivol \\ Escola Superior de Música de Lisboa, \\ Instituto Politécnico de Lisboa, Portugal
}

DOI: https://doi.org/10.31492/2184-2043.RILP2020.37/pp.173-190

\begin{abstract}
Resumo
Através deste artigo, e partindo da complexa e prolífica discussão teórica sobre a definição de jazz, pretendemos averiguar de que forma o ensino deste género musical poderá fornecer ferramentas necessárias ao crescimento artístico dos músicos. Com base em análise bibliográfica e experiência letiva, e tendo em conta o carácter dialógico dos binómios ensino formal-ensino informal e tradição-inovação recorrentes na discussão em torno deste assunto, iremos igualmente indagar sobre alguns dos contributos que o ensino do jazz poderá dar em termos do desenvolvimento de competências extramusicais.
\end{abstract}

Palavras-chave: jazz; ensino; improvisação; interação.

\begin{abstract}
With this article, departing form the complex and prolific theoretical discussion about the definition of jazz, we intend to inquire about the ways in which jazz education can provide the necessary tools for the artistic growth of musicians. Based on bibliographical analysis and teaching experience, and taking into account the dialogical nature of formal-informal education and tradition-innovation binomials that are frequent in the discussion about this topic, we will also investigate the contribution of jazz education in terms extra musical skills development.
\end{abstract}

Keywords: jazz; education; improvisation; interaction.

\section{Introdução}

Em The Teaching Of Jazz (1989), o reconhecido pedagogo Norte-Americano Jerry Coker aborda a problemática do ensino do jazz, referindo alguns dos seus aspetos mais relevantes. $\mathrm{O}$ intuito desta obra é fornecer ferramentas de ensino a professores de jazz, esclarecendo-os relativamente a questões como a planificação, modos de condução de diferentes tipos de aula (História de Jazz, Teoria do Jazz, Piano Jazz, Improvisação, Composição e Arranjo, etc.), principais referências bibliográficas, entre outras, assim como também justificar a necessidade da existência do ensino académico no jazz. Coker afirma que o ensino do jazz oferece ferramentas úteis e práticas para o desenvolvimento de músicos profissionais. Segundo o autor, muitos dos métodos que se utilizam no ensino deste género 
musical não se encontram em outros programas de ensino e contribuem para o desenvolvimento de músicos versáteis e completos (Coker, 1989, p.16).

Após reflexão acerca da abordagem de Coker, e apesar da ideia mais ou menos consensual de que o ensino formal do jazz constitui hoje pedra basilar no percurso de grande parte dos músicos (DeVeaux 1991, Reimann 2013), torna-se pertinente discutir neste artigo, a partir de análise bibliográfica, de trabalho de campo, e de experiência de ensino de mais de duas décadas, alguns dos contributos que o ensino formal do jazz poderá dar em termos do processo de formação não só musical, como também social e artística dos músicos. Contudo, questões como "Será que devem ou não existir cursos de jazz?", "Será que o jazz pode e deve ou não ser ensinado?" continuam a ser discutidos na literatura sobre ensino do jazz, nomeadamente nos trabalhos de Ake (2002a), Dunscomb (2002), Pinheiro (2011), Coker (1989), DeVeaux (1991), Reimann (2013), entre outros.

Coker afirma que, apesar da ideia inculcada no meio do jazz de que esta música tem como base a tradição oral e de historicamente a sua aprendizagem se revestir de um marcado carácter informal, o jazz pode efetivamente ser ensinado, uma vez existirem inúmeros métodos e outros instrumentos de ensino desenvolvidos ao longo dos anos que têm produzido resultados significativos, nomeadamente em termos da formação de artistas destacados (Coker 1989, p.16). A este respeito, podemos por exemplo referir o exemplo de músicos como Ambrose Akinmusire, Greg Osby, Lionel Loueke, ou Brad Mehldau. Por outro lado, dado o legado do ensino formal no universo do jazz, é inegável o seu estatuto enquanto forma de aprendizagem que ocupa um lugar cimeiro no contexto da história deste género musical (DeVeaux 1991, Murphy 1994, Prouty 2005).

No âmbito da discussão sobre de que forma a aprendizagem em contexto académico constitui um elemento preponderante na carreira profissional dos músicos de jazz, surgem, de forma natural, as seguintes questões: de que forma o ensino formal poderá potenciar o desenvolvimento de competências musicais (técnica do instrumento, estética e interpretação, aplicação da teoria musical na prática, improvisação, linguagem, performance a solo e em conjunto, leitura); até que ponto poderão coabitar processos formais e informais de aprendizagem nas instituições de ensino superior - e qual a sua importância no processo de formação dos músicos; de que forma práticas informais poderão ter origem ou ser adaptadas em instituições de ensino formal (concertos, jam sessions ${ }^{1}$ informais, jam sessions nas escolas, etc.); de que forma o ensino formal poderá contribuir para

1. De acordo com Pinheiro $(2011,2012)$ uma jam session define-se como "uma ocasião performativa idealmente aberta a qualquer músico que manifeste o desejo de participar. Realiza-se à noite semanalmente em bares e clubes de jazz, prologando-se até de madrugada. Partindo de um repertório padrão de "jazz standards", os músicos improvisam, desenvolvendo um diálogo musical, alicerçado predominantemente numa linguagem e estética musicais partilhada no meio do jazz, a "blues aesthetic". 
o processo de socialização dos músicos; de que forma o ensino formal poderá promover a integração destes no mercado profissional; de que forma o ensino formal poderá fomentar o desenvolvimento de competências no campo do empreendedorismo musical.

Para que seja possível responder a estas questões, torna-se fundamental aprofundar alguns temas que têm sido discutidos recorrentemente na literatura sobre o ensino do jazz.

\section{O que é "Jazz" e a importância da sua discussão}

Os autores Ake, Garrett, e Goldmark, na introdução de Jazz/not jazz: the music and its boundaries (2012) consideram que a classificação de estilos ou géneros musicais detém um papel fundamental na forma como se ensina, aprende, cria, acede e avalia a música (Ake et al., 2012, pp. 3-4). A questão sobre "o que pode ou não pode ser considerado jazz" ou simplesmente "o que é o jazz" tem acompanhado a história deste género musical e permanece atual, continuando a gerar substancial discussão e controvérsia. De acordo com Prouty (2012) "The boundaries of jazz have long been discussed and debated in the pages of magazines, newspapers, and journals, and in films and other media, as critics, scholars, and musicians have expressed opinions on what qualifies as "real jazz" (p. 70). Segundo Tucker (2012), "In jazz studies, as one can see quickly by reading recent titles of books, articles, and conference papers, many of us are not content to shore up a cohesive singular narrative about jazz, but we have been asking about the musics that were called jazz but are not called jazz now" (p. 276)². O jazz, género musical que existe há pouco mais de cem anos, esteve sempre em constante transformação, através da inspiração e contacto com diversas culturas, tradições e estilos musicais provenientes de vários pontos do mundo. Pelo facto de o jazz possuir como traço basilar um carácter culturalmente abrangente e inclusivo enquanto abordagem musical, é possível encontrar-se múltiplas definições em dicionários, livros de história e enciclopédias (Martin e Waters 2002, Gridley 2003, Jackson 2002). Apesar de este trabalho não ter como objetivo procurar uma definição objetiva de jazz, torna-se, contudo, pertinente discutir alguns aspetos que caracterizam este género musical, uma vez que diferentes abordagens à definição de jazz poderão configurar diferentes abordagens ao seu ensino.

É, pois, fundamental desenvolver-se reflexão em torno da definição de jazz, uma vez que o pedagogo deverá construir uma ideia clara sobre aquilo que está a ensinar, baseando-se em conceitos que se constituem enquanto alicerces históricos, 
estéticos e avaliativos deste género musical (Berliner 1994, Monson 1996, Jackson 1998 e 2002, Pinheiro 2011 e 2012).

De acordo com Mark Gridley, Robert Maxham e Robert Hoff (1989), o conceito de "jazz" foi sempre particularmente problemático e ambíguo relativamente ao seu significado, sendo que poucos autores se debruçam sobre a definição do termo. O problema ocorre nos casos em que os autores assumem que os leitores partilham a mesma ideia da definição. Após referirem diversas interpretações do termo "jazz" propostas por diferentes críticos, jornalistas e pedagogos, os autores Gridley, Maxham e Hoff, no seu artigo Three Approaches to Defining Jazz (1989), defendem que as várias aceções atribuídas a este termo levam a uma certa indefinição, o que impossibilita responder à questão "O que é o jazz?" de forma exata. De acordo com Gridley, Maxham e Hoff (1989):

\footnotetext{
"Jazz is not a musical form; it is a method of treatment. It is possible to take any conventional piece of music, and "jazz it". The actual process is one of distorting, of rebellion against normalcy" (Spaeth, S., 1928 em Gridley, Maxham e Hoff, 1989, p. 513).
}

"Jazz - dance music, generally syncopated, played by a band eccentrically composed. The jazz drummer, a sort of one-man band, provides the characteristic feature of jazz, which is noise..." (Chambers' Encyclopedia em Gridley, Maxham e Hoff, 1989, p. 513).

\begin{abstract}
"Jazz is a very big; it covers a multitude of sounds, all the way from the earliest Blues to Dixieland bands, to Charleston bands, to Swing bands, to Boogie- Woogie, to crazy Bop, to Cool Bop, to Mambo - and much more. It is all jazz... it is an original kind of emotional expression, in that it is never wholly sad or wholly happy... Rhythm is the first thing you associate with the word "jazz"... But jazz could not be jazz without its special tonal colors, the actual sound values you hear... A popular song doesn't become jazz until it is improvised on, and there you have the real core of all jazz: improvisation" (Bernstein, L., 1955 em Gridley, Maxham e Hoff, 1989, p. 514).
\end{abstract}

Dada a multiplicidade de noções de jazz existentes na literatura e no discurso dos músicos, Gridley, Maxham e Hoff identificam três grandes grupos de definições: a definição estrita (Strict Approach) que enfatiza a presença obrigatória do swing e da improvisação enquanto elementos essenciais do jazz; a abordagem por semelhanças familiares ("Family Resemblances" Approach) - em vez de ir à procura de uma única característica que percorre toda a história do jazz, pretende encontrar inúmeras características que se cruzam; e a abordagem do jazz enquanto dimensão (Approaching Jazz as a Dimension/Jazzness Approach) - dos elementos anteriores associados ao jazz, quanto maior o seu número e quanto mais clara for a sua identificação, mais uma performance pode ser classificada como jazz. Para concluir, Gridley, Maxham e Hoff afirmam que cada uma das três definições apresentadas no artigo, corresponde a três tipos de público diferentes: 


\begin{abstract}
"In conclusion, we feel that the definition having the greatest utility for scholars is the strict definition. Its simplicity allows us to determine what is not jazz, though it excludes much music that the public ordinarily calls jazz. That having the greatest utility for the public is the family resemblances approach because it allows the public to continue calling "jazz" anything they ever thought was jazz. The reprioritization of elements that is possible with the jazzness approach might reflect most adequately the changing nature of what is regarded as jazz from decade to decade, improvisation being most important sometimes, swing feeling other times, bluesy flavor other times. The definition by jazzness is probably the way the majority of jazz fans are responding" (Gridley, Maxham, Hoff, 1989, p.531).
\end{abstract}

A tentativa de objetivar o termo jazz poderá eventualmente tornar-se problemática, uma vez que este conceito tem sido utilizado em contextos variados para denominar um conjunto de práticas que podem ser bastante diferentes entre si. Um bom exemplo deste facto é o reconhecido festival "EDP Cool Jazz". A maioria dos artistas que têm integrado os cartazes do festival, apesar do seu reconhecimento, discutivelmente se enquadrarão no género considerado "jazz" pela maioria dos críticos, estudantes e entusiastas. Por outro lado, a discussão em torno do significado do conceito de "jazz" é importante no campo da pedagogia, uma vez que poderá determinar abordagens mais ou menos "tradicionais" relativamente às práticas estudadas. Por outras palavras, de acordo com a aceção de jazz adotada, poder-se-á dar maior predominância ao estudo de determinadas épocas e estilos em detrimento de outras.

\title{
Improvisação, ritmo, interação e a influência de outros géneros musicais
}

Não pretendendo aprofundar exaustivamente a discussão em torno das diversas abordagens sobre o significado do termo jazz, consideramos pertinente para os efeitos deste artigo enfatizar os seguintes aspetos relacionados com o género: a improvisação, os aspetos rítmicos, a comunicação musical entre os músicos no decurso da performance, e a influência proveniente dos outros géneros musicais. Os músicos são avaliados pelos seus pares com base em critérios como: o timbre (muitas vezes referido pelo conceito "sound"), a abordagem rítmica, o domínio da harmonia, o modo de frasear e encadear ideias musicais, e a capacidade e profundidade da interação com os membros do grupo (a este respeito ver também Berliner 1994 e Pinheiro 2011 e 2012). Aqueles que não apresentam um domínio destes parâmetros são criticados pelos seus pares, pelo facto de poderem comprometer a experiência musical dos restantes participantes (Pinheiro 2011, p. 8).

Tal como referido em Three Approaches To Defining Jazz (Gridley, Maxham, Hoff, 1989), e indo ao encontro de outras definições de jazz existentes, a improvisação constitui-se enquanto prática fundamental neste género musical. De acordo com Henry Martin (1986): “(...) jazz is a twentieth century music originated in 
America by black Americans and characterized by improvisation and a strong projection of rhythm" (Martin, 1986, p. 4).

A introdução do volume seminal intitulado Thinking in Jazz (1994) da autoria de Paul Berliner inicia- se com o capítulo Improvisation And Its Study. Ao referir definições do termo "improvisação" propostas por dois dicionários, Berliner aprofunda a discussão em torno do conceito de improvisação:

“(...) just what is improvisation? A popular general dictionary maintains that "to improvise is to compose, or simultaneously compose and perform, on the spur of the moment and without any preparation." Similarly, a prestigious music dictionary has, until recently, asserted that improvisation is the "art of performing music spontaneously, without the aid of manuscript, sketches or memory." Such definitions reflect the common view that the activity of improvisation comprises neither the faithful re-creation of a composition nor the elaboration of prefigured musical ideas. In the absence of such models or goals, it follows that there is no music for improvisers to prepare for performance. Indeed, they must perform spontaneously and intuitively" (Berliner. P., 1994, p. 17).

Larry Solomon, no artigo Improvisation II (1986), apresenta uma definição de "improvisação" referindo que o verdadeiro alvo dessa prática musical consiste na descoberta e invenção de música nova, que acontece de forma espontânea e no decurso de uma performance. De acordo com o autor:

"Improvisation involves making decisions affecting the composition of music during its performance. The fundamental ideal of improvisation is the discovery and invention of original music spontaneously, while performing it, without preconceived formulation, scoring, or content, although this is admittedly a limit case. It is improbable that the limit case of no preconception, either by design or past learning, actually exists. Therefore, improvisation is a matter of degree" (Solomon, L., 1986, p. 226).

Coker, Casale, Campbell e Greene (1970) corroboram a definição de Solomon, acrescentando que a arte da improvisação requer o "condicionamento do corpo, da mente e do espírito":

"Jazz improvisation is the spontaneous creation of music in the jazz style. Like traditional composition, jazz improvisation is a craft. It is a conditioning of the mind, body and spirit, brought about by the study of musical principles. This conditioning becomes a necessary prelude to the professional practice of the art, despite the implications of the word spontaneous" (Coker, J., Casale, J., Campbell, G., Greene, J., 1970).

A improvisação constitui-se enquanto capacidade musical que requer um considerável tempo de prática para ser desenvolvida. Principalmente se estivermos 
a falar da improvisação no contexto da "linguagem tradicional de jazz"3, muitas vezes a teoria e as ferramentas musicais necessárias a esse processo podem ser aprendidas e interiorizadas em relativamente pouco tempo, mas, para um músico se tornar um improvisador destacado no meio, podem ser nessessárias décadas de prática. De acordo com Jerry Coker:

"The theory and musical tools of improvisation may be mentally understood in a relatively short space of time, but the honing of the performance skills requires years. Successful levels of performance might be reached within a few years, but mastery is elusive and the improviser who continues to practice continues to improve for a lifetime" (Coker, J., 1989, p. 14).

Embora a componente da "tradição" que alguns músicos e pedagogos invocam enquanto pilar da aprendizagem do jazz seja importante, existe também a necessidade no meio de se procurar inovar a partir da informação tradicional aprendida previamente (Berliner, 1994). Muitas vezes, "o respeito pela tradição" pode ser confinado a uma mera imitação relativamente à forma como o jazz foi historicamente executado por figuras icónicas. Berliner afirma que os músicos que permanecem no "estádio da imitação", têm menos destaque do que aqueles que procuram inovar a partir da "tradição":

\begin{abstract}
Musicians who remain at the imitative end of the spectrum enjoy the least prestige. Some, having undergone the years of intensive training required to develop fundamental improvisation skills, succeed only in absorbing the most general performance conventions of a particular jazz idiom. Although at times receiving praise for "competence," they are often characterized as "generic improvisers." One unsympathetic artist views their solos as comprising "the same phrases you hear from everyone else, a string of acceptable, idiomatically correct pieces of jazz vocabulary, riffs, and motives - little figurations, all strung together in a trite and uninspired way" (Berliner, 1994, p. 205).
\end{abstract}

De qualquer das formas, e de acordo com vários autores como Berliner (1994), a imitação faz parte do processo normal de aprendizagem e do desenvolvimento inicial do indivíduo enquanto músico de jazz. Trata-se uma ferramenta de estudo útil, uma vez que é através da imitação que os músicos de jazz desenvolvem e assimilam a linguagem, nomeadamente as nuances da execução no instrumento, o rhythmic feel, entre outros aspectos relevantes. De acordo com Gary Bartz e Walter Bishop Jr. em Berliner (1994):

3. No meio do jazz, a formulação "linguagem tradicional de jazz" é utilizada para descrever um conjunto de abordagens variadas à construção de linhas melódicas, à harmonia tradicional do cancioneiro norte-americano, ao tempo e ao ritmo, à instrumentação e às técnicas expressivas, entre outros elementos musicais. Por norma, quando se refere "linguagem tradicional", fala-se na linguagem da era do Bebop que surgiu em meados dos anos 40 do século XX, e dos estilos que daí derivaram. 
“...Although imitation is a mode that all players go through in their formative years, the direction they take from there marks varying levels of achievement along the continuum from imitation to innovation. Soloists who have reached the assimilative stage command greater attention and respect than those who have not. For an individual "fully to play himself, rather than to sound like someone else, is possibly the hardest thing to do," Gary Bartz says candidly...

...On the grand scale of judging the overall contribution of the artist to jazz, a fundamental criterion for evaluation is originality, also a highly valued component within an individual solo. The categories against which improvisers evaluate originality correspond roughly to the definitive stages of artistic development described earlier by Walter Bishop Jr.: imitation, assimilation, and innovation. It is to be expected that only some individuals within the jazz community complete the succession of developmental stages and realize success within them...”(Berliner, 1994, pp. 204-205).

No meio do jazz, é também valorizada a capacidade de comunicação e interacção entre os músicos de um determinado grupo, no decurso da performance, e na sua espontaneidade. Por outro lado, a interacção do grupo com o público torna-se fundamental (Pinheiro, 2011, p. 7). Todos os elementos do grupo devem ouvir-se atentamente, contribuindo assim para a produção musical espontânea em tempo real e dentro de um determinado contexto. De acordo com Aaron Goldberg em Pinheiro (2011), a capacidade de ouvir e de comunicar entre os músicos durante a execução, constitui-se como uma das qualidades fundamentais para um bom desempenho numa performance:

Is he listening to the other musicians? Can you hear that he is interacting with them and what he is playing is changing basically what they are playing and he's leaving space foris ving space for him and there's a kind of communication going on? Does he have good communicative powers? (Pinheiro, 2011, p. 10).

A audição atenta é central, quer no jazz, quer noutros domínios musicais (Berliner 1994, Merriam 1964), sendo a imitação uma componente fundamental no processo de aprendizagem. (Pinheiro, 2011, p. 10). Ingrid Monson, na obra seminal Saying Something (1996), ao citar Herbie Hancock, compara uma performance de jazz a uma conversa:

\footnotetext{
"Musical intensification is open-ended rather than predetermined and highly interpersonal in character-structurally far more similar to a conversation than to a text. Herbie Hancock put it this way when talking about his experience with the Miles Davis Quintet in the early 1960s: "We were sort of walking a tightrope with the kind of experimenting that we were doing in music. Not total experimentation ... we used to call it "controlled freedom" ... just like conversation-same thing. I mean, how many times have you talked to somebody and ... you got ready to say, make a point, and then you kind of went off in another direction, but maybe you never wound up making that point but the conversation, you know, just went somewhere else and it was fine. There's nothing wrong with it. Maybe you like where you went. Well, this is the way we were dealing with music" (Monson, 1996, p. 81).
} 
Contudo e conforme já explicado anteriormente, torna-se hoje difícil de circunscrever o conceito de jazz enquanto prática musical (Jackson 2002). Se por um lado festivais utilizam o conceito de jazz com o propósito de vender uma imagem de sofisticação e intelectualidade, e nos quais a programação discutivelmente comtempla grupos conotados com deste género musical, por outro, alguns autores como Leonard Bernstein ${ }^{4}$ ou Willie Ruff ${ }^{5}$ (já referidos anteriormente e citados em Gridley, Maxham, Hoff, 1989) defendem que a música só pode ser considerada jazz se contemplar a prática da improvisação. Outros defendem a ideia de que o jazz só existe quando o swing ou o fraseado tradicional estiverem presentes $^{6}$ (Marsalis 1988). A verdade é que hoje em dia o jazz constitui-se enquanto género musical extremamente versátil e híbrido, resultante de diversas influências e transformações ao longo da sua história, e cuja definição se vai tornando cada vez mais vaga e abrangente.

\section{Poderá o Jazz ser ensinado? Se sim, através de que processos?}

Dados os manifestos problemas que decorrem da definição de jazz e a discussão em torno das características subjacentes a este género musical, surgem as seguintes questões: poderá o jazz ser ensinado? Será que este género musical deve ser ensinado? Se sim, que formatos e orientações pedagógicas poderá o ensino superior adotar?

Apesar de alguns discursos no meio do jazz reforçarem a construção da ideia de que a prática desta música impõe como condição sine qua non os músicos possuírem determinadas capacidades musicais inatas e uma ligação genética-racial a um "mito" Afro-Americano7 (Gioia 1989), é fundamental referir que a aprendizagem da música é, essencial e universalmente, um processo social de aprendizagem cultural (Merriam 1964, Blacking 1973 e 1995, Barton 2018). Jerry Coker, entre inúmeros outros autores, defende que o jazz pode ser ensinado,

4. "A popular song doesn't become jazz until it is improvised on, and there you have the real core of all jazz: improvisation” (Bernstein. L., "The World of Jazz” de CBS Omnibus Series, 1955 citado em Gridley, Maxham, Hoff, 1989, p. 514)

5. "More than anything else, jazz is a feeling, a way of playing music, a way a musician feels at any given time. It isn't written... we want to give musicians room to improvise... Another important ingredient in jazz is syncopation" (Ruff, W., Jazz For Juniors, 1958, citado em Gridley, Maxham, Hoff, 1989, p. 514).

6. "Though Tadd Dameron is not as well-known as many other giants, he was one of the finest composers jazz has produced. He created a body of material of great originality and personality that still addresses the fundamentals of jazz - blues and swing” (Marsalis, W., What Jazz Is - And Isn't - NY Times, 1988).

7. A este respeito, Gioia (1989) em "Jazz and the primitivist myth" aponta: "Goffin was perhaps even more extreme than Panassie in his emphasis on this "enlightened ignorance" of the jazz musician. "Louis Armstrong," he wrote in Jazz: From the Congo to the Metropolitan, "is a full- blooded Negro. He brought the directness and spontaneity of his race to jazz music" (Gioia, 1989, p.137). 
enfatizando a relevância dos métodos de ensino do jazz e os seus benefícios em termos do desenvolvimento de capacidades em estudantes que se tornaram mais tarde músicos destacados:

\begin{abstract}
"Despite the many myths and spoken clichés about jazz, like "You either got it or you ain't", "If you have to ask, don't mess with it", "Jazz can't be taught any more than composition can be taught", or "Teaching jazz creates a sterile product", the fact is that within this author's lifetime a multitude of effective methods and teaching tools have been created and developed for the teaching of jazz. Great number of succesfull jazz artists have benefited from those methods and tools already. Only the uninformed will continue to believe that jazz cannot be taught" (Coker, 1989, pp. 15-16).
\end{abstract}

O pianista, compositor e musicólogo David Ake (2002a) partilha da mesma opinião e acrescenta que até os mais talentosos terão necessariamente de trabalhar com o intuito de interiorizar os paradigmas estéticos e performativos vigentes no meio do jazz, e, numa segunda fase, desenvolver aqueles com os quais mais se identificam ${ }^{8}$ :

\begin{abstract}
I do not wish to suggest that jazz cannot lead, or has not led, to profoundly moving experiences for its adherents, or that it means the same thing to all cultural communities. But we should keep in mind that jazz, as with any cultural product, involves the manipulation of certain materials and the enactment of certain behaviours. And like painters, or writers, or weavers, jazz musicians can learn, indeed must learn the skills necessary to work in order that audiences may hear and see a particular musician's work as tunes, timbres, rhythmic feels and demeanours specific to jazz communities. Individuals are not "born to play jazz"; they play the music because they have heard it somewhere and, for a number of reasons, feel themselves intrigued enough to want to learn how to create it.
\end{abstract}

Of course, not all individuals possess equal aptitudes for all activities: "talent" does affect the rate at which, and the degree to which, individual players develop their skills. But talent always implies ability within a particular field, and even the most precocious prodigies must internalize the rules, styles and nor$\mathrm{ms}$ of their discipline, if only to reject some of them later. With that in mind, we can now turn to the ways in which musicians teach and learn the various rules, styles and norms of jazz. (Ake, D., 2002, p.257).

A ideia de David Ake, retirada do capítulo Learning Jazz, Teaching Jazz (2002a), é reforçada por outra que se encontra publicada na autobiografia de um dos mais influentes músicos do século XX - Miles Davis. De acordo com Davis:

\footnotetext{
"You don't just learn any of kind of shit like that naturally. That's something somebody teaches you, like when you teach somebody how to play a musical instrument correctly. After you've learned how to play your instrument the right way, you can turn around and play it the way you want to, anyway you hear the music and sound and want to play it. But you've got to first learn how to be cool and let whatever happens... happen. Dizzy and Bird taught it to me in music; so did Monk and so did Ahmad Jamal and Bud Powell" (Davis, 1998, p.182).
} 
O ensino do jazz oferece ferramentas úteis e práticas para o desenvolvimento de músicos profissionais, como por exemplo as disciplinas de treino auditivo, prática de conjunto, improvisação, teoria de jazz, composição e arranjo, entre outras (Coker, 1989). De acordo com o anteriormente discutido neste artigo, o ensino do jazz contribui com a introdução de metodologias que levam ao desenvolvimento de capacidades como a improvisação, interação, sendo estas complementares àquelas utilizadas no ensino de outros géneros musicais, como é o caso da música erudita. Coker afirma: "Finally, the teaching techniques of jazz, in their presently developed state, offer a unique brand of training found nowhere else in non-jazz music programs, and those new techniques engender a well- rounded sort of musicianship" (Coker, 1989, p. 16).

Vários outros pedagogos, como por exemplo Ed Sarath ${ }^{9}$ têm-se destacado pelo amplo trabalho desenvolvido no ensino destes conteúdos a alunos de outras áreas musicais distintas do jazz, enfatizando o benefício do estudo da improvisação em outros contextos musicais:

\footnotetext{
Although jazz was central to my job description, I had designed unique approaches to not only jazz improvisation but also stylistically open improvisation that provided classical (and other) musicians "user-friendly" entryways into the process. Instead of imposing external style constraints at the outset, my approach elicits a creative flow from whatever style backgrounds musicians bring to the process.. While students and faculty alike would commonly report some degree of fulfillment even from their initial improvisatory attempts, and furthermore noted positive benefits that transferred to their interpretive performing such as greater freedom, expressivity, and sharper listening skills, I became acutely aware of an important deficiency that needed to be addressed. (Sarath, 2013, p. 6)
}

Relativamente aos putativos formatos que o ensino do jazz poderá seguir, subsiste no meio a ideia bipolarizada de que, por um lado, o jazz deve ser transmitido através de processos informais, e, por outro, de que este género musical se constitui enquanto género passível de ser ensinado em instituições de ensino formal (Pinheiro 2011).

Alguns agentes do meio (músicos, historiadores, críticos) defendem que o jazz deve ser aprendido na "rua", e alegam a importância histórica dos métodos informais de aprendizagem através da observação de concertos, escuta de discos, e imitação. Em Aprender Fora de Horas: A Jam Session em Manhattan Enquanto Contexto Para a Aprendizagem do Jazz (2012), a partir de trabalho de campo realizado em Nova Iorque, Pinheiro revela a importância dos meios

9. "In 1987, I was appointed to the music faculty at the University of Michigan to establish a program in jazz studies. I came in with bold ambitions: First, I would bring jazz and improvised music to the majority of students and faculty at this top-ranked, largely classical performing arts school, a task that I estimated could be completed in a few years" (Sarath, 2013, p. 6). 
de aprendizagem informal no jazz, nomeadamente a jam session, uma "ocasião performativa idealmente aberta a qualquer músico que manifeste o desejo de participar" (Pinheiro, 2011):

\begin{abstract}
"Conforme veremos, no contexto de jam sessions, músicos aprendem no "acto de fazer", adquirindo experiência performativa, uma sonoridade pessoal, conhecimento do repertório, e uma postura profissional. Muitos dos interlocutores perspectivam a aprendizagem em jam sessions como um complemento essencial ao ensino formal do jazz em conservatórios e universidades. Defendo que, para além das instituições de ensino formal, a jam session constitui um importante contexto para a aprendizagem informal do jazz, proporcionando o contacto entre aprendizes e os mais diferentes agentes educativos. Se interpretarmos os dados aqui apresentados à luz da teoria do ritual, verificamos que as jam sessions envolvem comunicação (...), celebram e asseguram a unidade e continuidade do grupo, podendo ainda estimular a transformação deste e do indivíduo (...)" (Pinheiro, 2011, p. 4).
\end{abstract}

As jam sessions e outros métodos informais de aprendizagem estão patentes na história desta música, nomeadamente no percurso de nomes destacados como Buddy Bolden, Charlie Parker, Louis Armstrong, entre outros. David Ake (2002a) afirma que inúmeros músicos proeminentes, após terem ganho exposição mediática, passaram a ser "heróis do bairro", influenciando e motivando jovens-músicos a iniciar o seu percurso musical:

"But local jazz learning also occurs outside formal student-teacher relationships. Hearing a parent, sibling, friend or neighbor during a performance or practice session may motivate a child to pick up an instrument and to follow that older player into music. For instance, Coleman Hawkins stood as a neighbourhood hero to Harlem youths in the 1930s and 1940s, his exceptional musical ability and professional success inspiring a number of local children, including Sonny Rollins, to learn to play" (Ake, 2002, p.258).

Jerry Coker afirma que, para além do "talento", o facto de os músicos possuírem objetivos claramente definidos e um forte e constante desejo de os alcançar, constituiu a principal razão do sucesso de artistas destacados, apesar da falta de educação formal no seu percurso (1989). No livro Jazz Cultures (2002b), David Ake refere que o reconhecido saxofonista, clarinetista e compositor Sidney Bechet recusava voluntariamente aprender notação musical, pelo que terá sido criticado pelos seus pares:

"Despite his Creole background, Bechet always remained an "ear" player, staunchly refusing to learn musical notation, an aspect of his musicianship roundly criticized by many of his fellow Downtown players, with their pride in European-style "professionalism.” Jazz historians Lewis Porter and Michael Ullman understood Bechet's inability to read music as a "failing" about which he was "sensitive." But far from being defensive about this issue, Bechet makes it plain in his autobiography that his decision not to read was a conscious one. Such a stance can be seen as evidence of his desire to be linked with 
what he must have regarded as the more "pure" Uptown style of musical expression. He was not alone in his mistrust of reading. Nat Hentoff and Nat Shapiro quote Jack Weber as saying of early New Orleans clarinetists that "some of them thought that if they learned how to read, it would ruin their ability to improvise." One explanation for this stance may be that the Uptown players, those most inclined to rely solely on their "ears," were by necessity the strongest improvisers, and improvisational ability remained one of the traits that Bechet and like-minded players esteemed most highly in a musician" (Ake, 2002b, pp. 24-25).

Contudo, as aptidões necessitam de ser praticadas e desenvolvidas, independentemente da origem dos métodos de aprendizagem. Coker (1989) afirma que, mesmo no caso de "génios" como Louis Armstrong ou Charlie Parker, um programa educacional na área do jazz poderia ter contribuído de forma a acelerar o desenvolvimento musical oferecendo-lhes ferramentas adicionais para utilização na sua vida profissional. Além disso, segundo Coker, um programa educacional atual na área do jazz baseia-se fortemente na aprendizagem através da audição, transcrição e imitação dos artistas mais destacados da história da música.

As instituições académicas que ministram ensino do jazz constituem-se também enquanto ponto privilegiado para o encontro de jovens motivados e com objetivos semelhantes. Este facto permite aos estudantes aprender não só com os professores e os seus métodos, mas também com os colegas. Berliner (1994) afirma que as escolas oferecem meios através dos quais os alunos conseguem criar laços mediados pela partilha de interesses musicais, o que, de certa forma, influencia de igual forma o seu futuro profissional:

\footnotetext{
Musicians describe their classes as useful forums for reinforcing or supplementing the knowledge about jazz that many had acquired as youngsters. At the same time, most stress the importance of jazz performance in college. In the face of the jam session's decline and of decreasing employment opportunities with road bands, colleges provide an environment where students can interact with peers who share their concerns. At Lincoln University, Ronald Shannon Jackson occupied a dormitory room with John Hicks, and he formed close friendships with other serious jazz musicians in the student body, students like Oliver Lake. Throughout their undergraduate days, the friends "spent as much time performing together as studying" (Berliner, 1994, p. 55).
}

Por último, torna-se fundamental referir a razão pela qual as instituições de ensino superior e outras escolas devem continuar a apostar no ensino do jazz. Em primeiro lugar, os cursos de jazz continuam a ganhar popularidade no meio musical - por exemplo, a Escola Superior de Música de Lisboa do Instituto Politécnico de Lisboa tem uma média anual de 140 candidatos à licenciatura em Música, Variante Jazz. Os cursos de jazz atraem o interesse de alunos provenientes das mais variadas áreas musicais, contribuindo de forma muito positiva para a diversidade estética e cultural da comunidade escolar. Por outro lado, o ensino formal 
do jazz contribui de uma forma muito positiva para a visibilidade das instituições. Segundo Coker (1989, p.19), o ensino do jazz ajuda as instituições a criar uma imagem de progresso e versatilidade, o que se poderá refletir num eventual incremento de apoios em termos de financiamento. Os alunos e os grupos mais destacados participam frequentemente em concursos e festivais, contribuindo assim para a visibilidade e imagem de qualidade das instituições de ensino.

Podemos ainda referir que muitas das competências desenvolvidas no âmbito do processo de ensino-aprendizagem do jazz poderão extravasar o universo da música. David Liebman (2012), proeminente saxofonista, compositor e pedagogo, defende que, no âmbito do processo de aprendizagem da improvisação, os jovens músicos desenvolvem competências relacionadas com a demonstração de quem são e o que representam, refletindo, através de profundos aspetos filosóficos e espirituais, a sua condição enquanto seres humanos. Segundo Liebman, o ensino do jazz promove igualmente o desenvolvimento de capacidades de liderança. Com efeito, no decurso do processo improvisativo, os músicos terão de aprender a assumir a liderança, promovendo a mudança quando e se necessário, ao mesmo tempo que deverão prescindir do papel de líderes de forma incondicional quando a situação assim o exigir (por exemplo, quando se procede à mudança de solista ou à exposição do tema).

Por outro lado, os músicos de jazz aprendem a perspetivar a improvisação enquanto atividade que envolve multitasking, ou seja a capacidade para realizar múltiplas ações de forma simultânea. Os estudantes de jazz, através da aprendizagem musical, desenvolvem a capacidade para lidar de forma rápida e simultânea com informação variada, assim como também para integrar e sintetizar essa informação de uma forma criativa (Liebman, 2012).

O jazz potencia igualmente o desenvolvimento de um processo de ensino-aprendizagem caracterizado pelo sistema mentor-aprendiz. Segundo Liebman (2012), a aceitação da informação veiculada por um mentor, através de um procedimento experiencial, implica a suspensão do julgamento relativamente ao valor pessoal e imediato do material lecionado. A autor alerta igualmente para o facto de que aprender jazz implica forçosamente o desenvolvimento de um sentido de respeito mútuo. Segundo Liebman (2012), constitui prática diária participar num esforço coletivo, através da colaboração em grupo. A aprendizagem do jazz promove assim a construção de uma atitude aberta e de respeito para com os restantes membros do grupo, através de trabalho conjunto entre pares, independentemente da idade, género, nível de desenvolvimento instrumental e conceptual, nacionalidade, raça ou religião. 
O ensino do jazz potencia também o crescimento pessoal em termos de clareza de visão, uma vez que desenvolve no músico a noção de que este possuí uma voz única. Através do aperfeiçoamento das suas conceções estéticas e filosóficas, este acaba por ter de assumir um papel ativo na criação e na mudança musical através do emprego de ideias únicas e pessoais. Este processo envolve pensamento crítico e criativo, autoavaliação, disciplina e o intuito de mudar o status-quo em prol da descoberta de uma melhor forma de atingir determinados objetivos musicais.

Podemos argumentar também que o ensino do jazz pode promover flexibilidade a vários níveis. Conhecer o repertório standard (isto é, a história e tradições do género musical), expandindo o desejo e competência para reconfigurar de forma criativa um conjunto de normas, tanto espontaneamente, como através do planeamento antecipado, fomenta o desenvolvimento de uma personalidade maleável capaz de se adaptar às mais variadas circunstâncias da vida. Segundo Liebman (2012), o estudo do jazz potencia a capacidade de ajuste e de mudança de direção a partir de um conjunto de normas e condições que poderão encorajar descobertas inovadoras. Por outro lado, o ensino do jazz poderá incutir aos formandos princípios de compromisso. Por exemplo, ser capaz de "swingar", ou seja, fazer parte do contexto rítmico envolvente ou groove, constitui uma capacidade valiosa em termos do saber fazer parte do processo criativo. O estudo do jazz constitui-se igualmente fundamental na promoção da criatividade individual. Compor música original ou realizar arranjos de obras já existentes desperta a capacidade de criação de algo novo ou de modificação de uma tradição ou prática previamente estabelecidas, com base na imaginação, competências e experiências pessoais.

O estudo do jazz promove igualmente o desenvolvimento da consciência, ou seja, da capacidade para registar e avaliar o que se passa à nossa volta. Isto resulta da experiência ganha em contexto de prática de música de conjunto, no âmbito da qual os músicos têm de ouvir, processar e responder aos múltiplos estímulos com os quais são confrontados. Este facto potencia também o desenvolvimento de uma atitude aberta relativamente a tudo aquilo que é novo e inesperado, sem receio ou julgamento imediato daquilo que nos é apresentado. Conduz igualmente à perceção de que tudo aquilo que é novo provém do "velho", devendo ser aceite e alvo de um processo de amadurecimento e adequação às especificidades de uma situação concreta.

O ensino do jazz promove definitivamente capacidades de interação em palco, de comunicação com a audiência, e de trabalho no seio da comunidade musical mais próxima. O desenvolvimento de um espírito de cidadania resulta na consciência da nossa relação para com o ambiente social e de trabalho que nos rodeia, 
assim como para com a sociedade em geral. De acordo com Liebman (2012), trata-se da capacidade para ver a big picture tanto na nossa vida privada como na vida pública.

O estudo do jazz implica igualmente o desenvolvimento de capacidades de comunicação. Aprender música em geral e jazz em particular pressupõe o amadurecimento de princípios de entretenimento e de partilha de informação. Estas competências são essenciais para se chegar à noção da componente social e propósito do trabalho, principalmente no que diz respeito ao processo de apresentação das criações por forma a que estas possam chegar com sucesso ao público.

Finalmente, de acordo com Liebman (2012), a aprendizagem do jazz promove o desenvolvimento de princípios de espiritualidade. A condição artística pressupõe o reconhecimento de valores profundos e intrínsecos àquilo que fazemos na vida, tanto em termos práticos como espirituais. Pressupõe igualmente o desenvolvimento de capacidades de comunicar valores universais tais como a beleza, a verdade, a compaixão, de uma forma que ao mesmo tempo educa e entretém.

\section{Conclusões}

Apesar de se tratar de um género musical complexo em termos da sua definição, e de existir um extenso debate na literatura em torno dos mais variados processos formais e informais de aprendizagem, podemos argumentar que o jazz se constitui enquanto plataforma de desenvolvimento das mais variadas competências, musicais, estéticas, sociais e humanas.

Com efeito, o ensino do jazz pode contribuir ativamente para a formação de cidadãos mais preparados para os desafios que a sociedade lhes coloca. Os princípios e capacidades musicais desenvolvidos podem muito bem ser direcionados para a vida quotidiana fora da música, nomeadamente através do desenvolvimento de competências tais como a honestidade, liderança, clareza de pensamento, respeito, flexibilidade e capacidade de adaptação a diferentes situações, capacidade de compromisso, criatividade individual e coletiva, consciência da relação com o meio-ambiente, cidadania, capacidade de comunicação, e espiritualidade.

Esperamos que este trabalho estimule a investigação e reflexão sobre o ensino e aprendizagem do jazz em Portugal e no mundo lusófono.

\section{Referências}

Ake, D. (2002a). Learning jazz, teaching jazz. In The Cambridge Companion to Jazz (pp. 253269), ed. Mervyn Cooke e David Horn. Cambridge University Press.

Ake, D. (2002b). Jazz cultures. Berkeley, CA: University of California. 
Ake, D., Garrett, C. H. \& Goldmark, D. (2012). Introduction. In Ake, D. A., Garrett, C. H. \& Goldmark, D. (Eds.), Jazz/not jazz: the music and its boundaries (pp. 1-10). Berkeley: University of California Press.

Barton, G. (2018). Music Learning and Teaching In Culturally And Socially Diverse Contexts: Implications For Classroom Practice. Cham, Switzerland: Palgrave Macmillan.

Berliner, P. F. (1994). Thinking in jazz: The infinite art of improvisation. Chicago: University of Chicago Press.

Blacking, John. (1973). How Musical Is Man? Seattle: University of Washington Press.

Blacking, John. (1995). Music, Culture and Experience. Selected Papers of John Blacking. Chicago: The University of Chicago Press.

Coker J., Casale, J., Campbell, G., and Greene, J. (1970). Patterns for jazz. Lebanon, IN: Studio Publications.

Coker, J. (1989). The teaching of jazz. Rottenburg N., Germany: Advance Music.

Davis, M., \& Troupe, Q. (1998). Miles: The autobiography. London: Picador.

DeVeaux, Scott. (1991). Constructing the Jazz Tradition: Jazz historiography, Black American Literature Forum 25, (3): pp. 525-60.

Dunscomb, J. R., \& Hill, W. (2002). Jazz pedagogy: The jazz educators handbook and resource guide. Van Nuys, CA: Alfred Publishing.

Gioia, Ted. (1989). “Jazz and the Primitivist Myth”. Musical Quarterly 73:1: 130.

Gridley, M., Maxham, R., \& Hoff, R. (1989). Three Approaches to Defining Jazz. The Musical Quarterly,73(4), pp. 513-531.

Gridley, M. (2003). Jazz styles: history and analysis. New Jersey, Upper Saddle River.

Jackson, T. A. (1998). Performance and Musical Meaning: Analysing “Jazz” on The New York Scene (PhD Thesis). Columbia University.

Jackson, T. A. (2002). Jazz as musical practice. In M. Cooke \& D. Horn (Eds.), The Cambridge Companion to Jazz (pp. 83-95). Cambridge, UK: Cambridge University Press.

Liebman, D. (2012, September 26). Jazz Education In The Century Of Change: Beyond The Music. All About Jazz. Retrived from https://www.allaboutjazz.com/jazz-education-in-the-century-of-change-beyond-the-music-dave-liebman-by-david-liebman.php

Marsalis, W. (1988, July 31). What Jazz Is - And Isn 't. New York Times, pp. 21-24.

Martin, H. (1986). Enjoying jazz. New York: Schirmer Books.

Martin, H. and Keith Waters. (2002). Jazz: The First 100 Years. Belmont, CA: Schirmer/Thomson Learning.

Merriam, Alan. (1964). The Anthropology of Music. Northwstern University Press.

Monson, I. (1996). Saying something: Jazz improvisation and interaction. Chicago: University of Chicago Press.

Murphy, D. (1994) Jazz Studies in American Schools and Colleges: A Brief History, Jazz Educators Journal 26: pp. 34-38 
Pinheiro, R. F. (2011). Aprender Fora de Horas: A Jam Session em Manhattan Enquanto Contexto Para a Aprendizagem do Jazz. Acta Musicológica, 83(1): pp. 113-134.

Pinheiro, R. F. (2012). Jazz fora de horas: Jam sessions em Nova Iorque. Lisboa: Universidade Lusíada Editora.

Pinheiro, R. F. and Alexandre Diniz. (2019). (De)Constructing Jazz through its performers, repertoire, and musical process: a comparison between Herbie Hancock's boundary-defying albums Possibilities and River: The Joni Letters. Jazzhitz 2: pp 49-64.

Prouty, K. E. (2005). The History of Jazz Education: A Critical Reassessment. Journal of Historical Research in Music Education 26 (2): pp. 79-100.

Prouty, K. E. (2012). Creating Boundaries in the Virtual Jazz Community. In D. Ake, C. Garrett, \& D. Goldmark, Jazz/not jazz: The music and its boundaries (pp. 70-88). Berkeley: University of California Press.

Reiman, H. (2013). Jazz Education and the Jazz Periphery: An Example from Estonia. Journal of Music History Pedagogy 3 (2), pp. 183-185.

Sarath, E. (2013). Improvisation, creativity, and consciousness: Jazz as integral template for music, education, and society. Albany, NY: State University of New York.

Solomon, L. (1986). Improvisation II. Perspectives of New Music,24(2), 224.

Tucker, S. (2012). Deconstruction the Jazz Tradition, the "Subjectless" Subject of New Jazz Studies. In D. Ake, C. Garrett, \& D. Goldmark, Jazz/not jazz: The music and its boundaries (pp. 264284). Berkeley: University of California Press.

Data receção: 20/08/2019

Data aprovação: 19/06/2020 